\begin{tabular}{|c|l|}
\hline Title & $\begin{array}{l}\text { Seasonal variation of levoglucosan in aerosols over the western North Pacific and its assessment as a biomass burning } \\
\text { tracer }\end{array}$ \\
\hline Author(s) & Mochida, Michihiro; Kawamura, Kimitaka; Fu, Pingqing; Takemura, Toshihiko \\
\hline Citation & $\begin{array}{l}\text { Atmospheric Environment, 44(29), 3511-3518 } \\
\text { https://doi.org/40.1016/.atmosenv.2010.06.017 }\end{array}$ \\
\hline Issue Date & 2010-09 \\
\hline Doc URL & http://hdl.handle.net/2115/49421 \\
\hline Type & article(author version) \\
\hline File Information & AE44_29_3511-3518.pdf \\
\hline
\end{tabular}

Instructions for use 


\title{
Seasonal variation of levoglucosan in aerosols over the western North Pacific and its assessment as a biomass-burning tracer
}

\author{
Michihiro Mochida $^{\mathrm{a}, *}$, Kimitaka Kawamura ${ }^{\mathrm{b}}$, Pingqing Fu ${ }^{\mathrm{b}}$, and Toshihiko Takemura ${ }^{\mathrm{c}}$ \\ ${ }^{a}$ Institute for Advanced Research, Nagoya University, Furo-cho, Chikusa-ku, Nagoya 464-8601, Japan \\ ${ }^{\mathrm{b}}$ Institute of Low Temperature Science, Hokkaido University, N19 W8, Kita-ku, Sapporo 060-0819, Japan \\ ${ }^{\mathrm{c}}$ Research Institute for Applied Mechanics, Kyushu University, 6-1 Kasuga-koen, Kasuga 816-0811, Japan
}

\author{
*Corresponding author \\ E-mail address: mochida @iar.nagoya-u.ac.jp (M. Mochida), Phone/FAX: +81-52-788-6157
}

\begin{abstract}
Levoglucosan is considered as a useful molecular tracer of biomass-burning aerosols in the atmosphere. To characterize the seasonal variation of its concentrations over the Pacific Ocean and to assess its usefulness as a tracer after long-range transport, we investigated long-term variations of levoglucosan over Chichi-jima in the western North Pacific, from 2001 to 2004. Organic carbon (OC), elemental carbon (EC) and D-glucose were analyzed for comparison. The seasonal variation of levoglucosan concentrations shows a maximum in the winter, which is consistent with the enhanced Asian outflow to the Pacific indicated by backward air-mass trajectories. The concentration levels of levoglucosan estimated from global aerosol model outputs in the winter are, on average, comparable to the observed levels, suggesting that a considerable fraction of levoglucosan did not decompose during long-range transport from the Asian continent by westerly/northwesterly winds. This result is supported by comparable ratios of levoglucosan to EC in Chichi-jima and the East Asian coastal region. Conversely, the measured concentrations of levoglucosan in the summer are significantly lower than the modeled one. This implies a degradation of levoglucosan in the air masses that stagnated over the Pacific, although uncertainties in the model estimate may also be partly responsible for this discrepancy. One possible degradation pathway is oxidation by OH radicals; the contribution of acid-catalyzed reactions needs further investigation.
\end{abstract}

Keywords: Levoglucosan, Biomass-burning aerosol, Long-range transport, Organic carbon, Molecular marker 


\section{Introduction}

Biomass burning, associated with both open and domestic fires, is one of the main sources of atmospheric aerosols on the global scale. Levoglucosan (1,6-Anhydro- $\beta$-D-glucopyranose) is a major pyrolysis product of cellulose and hemicellulose, and has recently been highlighted as a useful molecular marker of biomass-burning aerosols (Simoneit, 2002). The advantage of levoglucosan over the conventional biomass-burning tracer, potassium, is that it is specific to biomass burning: no other sources are known to exist to date. In a number of source emission studies, levoglucosan has been reported to be most abundant in lists of individual detected particulate organic compounds (e.g., Schauer et al., 2001). Furthermore, levoglucosan has also been detected in a number of ambient studies (e.g., Graham et al., 2002; Puxbaum et al., 2006; Feng et al., 2007). The existence of levoglucosan in aerosols in remote marine (e.g., Mochida et al., 2003a) and polar regions (e.g., Stohl et al., 2007) indicates its long-range transport capability. Because levoglucosan is also detected in sediments (Elias et al., 2001) and Antarctic ice (Gambaro et al., 2008), its application to paleo-environmental studies is potentially important, as well.

In previous studies, levoglucosan was used to qualitatively and quantitatively assess the contribution of biomass-burning smoke to the aerosol mass (e.g., Puxbaum et al., 2006). While a number of studies reported short-term variations of levoglucosan, studies on long-term variations (e.g., Puxbaum et al., 2006) are not sufficient to understand the spatial and temporal distributions on a global scale. In particular, little is known about the abundance of levoglucosan in areas distant from biomass-burning sources or its usefulness as a tracer after long-range transport (Hofmann et al., 2010). In this study, we observed levoglucosan for three years over the Island of Chichi-jima in the western North Pacific, which is located $2000 \mathrm{~km}$ from the Asian continent and is under the influence of Asian outflow (e.g., Kato et al., 2001). We discuss the concentration levels, temporal variation, and abundance relative to carbonaceous components in view of the long-range transport from the source regions. Furthermore, these characteristics are compared to values reported in previous studies and estimates obtained from a global aerosol model to assess the usefulness of levoglucosan as a biomass-burning tracer at a remote marine site.

\section{Methods}

\subsection{Aerosol sampling and chemical analysis}


Total suspended particles (TSP) in the air were collected at a flow rate of ca. 700 standard $\mathrm{L} \mathrm{min}^{-1}\left(0^{\circ} \mathrm{C}\right.$, $1013 \mathrm{hPa}$ ) using a high-volume air sampler (AS-810A, Kimoto Electric Co. Ltd.) and quartz fiber filters (QFFs, $20 \times 25 \mathrm{~cm}$, Pallflex 2500QAT-UP) at the Ogasarawa Downrange Station (ODRS; $27^{\circ} 04^{\prime} \mathrm{N}$, $142^{\circ} 13^{\prime} \mathrm{E}, \sim 200 \mathrm{~m}$ asl) of the Japan Aerospace Exploration Agency (JAXA) on the island of Chichi-jima (Fig. 1). Because the area and population of the island are small (population: $~ 2000$; area: $24 \mathrm{~km}^{2}$ ) and because the ODRS site has been demonstrated to be suitable for observing long-range-transported aerosols (e.g., Mochida et al. 2003b), we regard the perturbation caused by local biomass-burning emissions as insignificant. QFFs were precombusted at $450{ }^{\circ} \mathrm{C}$ for $\geq 3 \mathrm{~h}$ prior to sample collection. Among collected samples, the 148 samples collected on a quasi-weekly basis from January 2001 to January 2004 were subjected to data analysis. Air was drawn through a QFF for 1-10 d (mean: 4 d) per sample. Air volumes measured by a mass flow meter were converted to those at $20^{\circ} \mathrm{C}$ and $1013 \mathrm{hPa}$. The QFFs were placed in glass bottles and stored in freezers.

Levoglucosan and D-glucose on the QFFs were quantified by analyzing trimethylsilyl (TMS) derivatives using gas chromatography-mass spectrometry (GC-MS), according to the method outlined in Wang and Kawamura (2005). More details are presented in the supplemental material. We found that the GC-MS responses of the sugar derivatives decrease nonlinearly when the amounts injected into the GC/MS were less than a few ng (see the supplemental material and Fig. S1). The resulting bias of atmospheric concentrations is estimated and presented as bars on the markers in the figures in this paper. Because only large variations in the levoglucosan concentration (e.g., order(s) of magnitude) are discussed, the bias is not critical and values without the correction are presented in the text and tables. Organic carbon (OC) and elemental carbon (EC) on QFFs were quantified by the thermal optical transmittance method with the IMPROVE temperature protocol (e.g., Chow et al., 2001) using an OC/EC analyzer (Sunset Laboratory Inc.). Screening of the data for the QFF samples is explained in the supplemental material. In this paper, concentrations of levoglucosan, OC and EC in TSP are compared to those of $\mathrm{PM}_{2.5}$ and $\mathrm{PM}_{10}$ at other sites and in biomass burning source emissions reported in the literature. Since these components are in general predominantly present in the fine mode (e.g., Mochida et al., 2007; Wang et al., 2009), the comparison is reasonable and helpful in understanding large differences or similarities in concentration levels. The OC and EC values quantified by different methods are also compared, although some biases could originate from the differences in the methods.

\subsection{Backward air-mass trajectories and global aerosol model}


The NOAA/ARL HYSPLIT model (http://www.arl.noaa.gov/ready/hysplit4.html; Draxler and Hess, 1997, 1998) was used to calculate ten-day backward trajectories for air masses that arrived over Chichi-Jima. The start height of the trajectories presented in the main paper is $500 \mathrm{~m}$ amsl. Trajectories at $1000 \mathrm{~m}$ and $2000 \mathrm{~m}$ amsl were also calculated (see the supplemental material); the horizontal patterns are in general similar to those at $500 \mathrm{~m}$. Considering changes in air mass origins during the sampling time (mean: $4 \mathrm{~d}$ ), we calculated the trajectories that arrived every $24 \mathrm{~h}$ at $2100 \mathrm{LT}(1200 \mathrm{UT})$ between the initial placement and the final collection of each QFF. Temporary outage of electricity for the sampler was not taken into account for the selection of the start time.

The concentrations of levoglucosan over Chichi-jima were estimated based on the concentrations of OC and BC calculated using the Spectral Radiation-Transport Model for Aerosol Species (SPRINTARS; Takemura et al., 2000; Takemura et al., 2009; see the supplemental material for details). Here, the BC in SPRINTARS are assumed to be equal to EC. The OC and EC at the surface of Chihi-jima were calculated with and without the emissions from biomass-burning sources. The differences were approximated to be OC and EC from biomass-burning sources, which are referred to as $\mathrm{OC}_{\mathrm{BB} \text {,model }}$ and $\mathrm{EC}_{\mathrm{BB} \text {,model }}$, respectively. Negative values of $\mathrm{OC}_{\mathrm{BB} \text {,model }}$ and $\mathrm{EC}_{\mathrm{BB} \text {,model }}$ were not used for the analysis. The total $\mathrm{OC}$ (or total $\mathrm{EC}$ ), including those from biomass-burning sources, are referred to as the $\mathrm{OC}_{\text {model }}$ ( or $\left.\mathrm{EC}_{\text {model }}\right)$. The concentrations of levoglucosan was estimated by multiplying the $\mathrm{OC}_{\mathrm{BB} \text {,model }}$ (or $\mathrm{EC}_{\mathrm{BB} \text {,model }}$ ) by the ratios of levoglucosan to $\mathrm{OC}$ (or $\mathrm{EC}$ ) in the literature. Among the reported source profiles, we selected the profile of Chinese cereal straw burning (Zhang et al., 2007) because biomass burning in China should strongly affect the concentrations of levoglucosan over Chichi-jima, as discussed below. The degradation of levoglucosan was not considered in the model.

\section{Results and Discussion}

\subsection{Seasonal variations of levoglucosan, $\mathrm{OC}$ and $\mathrm{EC}$}

Fig. 2a presents the three-year temporal variation in the concentrations of levoglucosan over Chichi-jima. The concentrations ranged from 0.017 to $15 \mathrm{ng} \mathrm{m}^{-3}$. Although the concentrations varied significantly from sample to sample, a seasonal variation was observed with a maximum in the winter. The means and ranges of the concentrations of levoglucosan in four seasons are summarized in Table 1. The seasonal mean was highest in December-February (winter, $2.2 \mathrm{ng} \mathrm{m}^{-3}$ ) and lowest in June-August (summer, $0.32 \mathrm{ng} \mathrm{m}^{-3}$ ). The seasonal variation of levoglucosan was similar to those of low-molecular-weight dicarboxylic acids (Mochida et al., 2003b) and terrestrial lipid class compounds (Kawamura et al., 2003) observed at ODRS, Chichi-jima in 
different years. As discussed previously, the variation can be explained by the transport of organics under the influence of the Asian monsoon system. In the summer, maritime air masses reached Chichi-jima under the influence of the Pacific anticyclone. In the winter, westerly or monsoon northwesterly winds caused by the Siberian anticyclone dominate, transporting air masses from East Asia to Chichi-jima.

This explanation is supported by the relation between air mass trajectories and the concentrations of levoglucosan. Figures 3a-d present ten-day backward trajectories for the measurement periods, which are classified into four seasons. The concentrations of levoglucosan, which are quantitatively shown by the colors of the trajectories, were high mostly when air parcels were transported from northeast China, east Siberia, Korea and Japan, from autumn to spring. Lower concentrations were observed more frequently when air masses were over the Pacific for more than ten days from spring to autumn. The mean transport time of air masses from the East Asian coastal region (for the area of $35-40^{\circ} \mathrm{N}, 120-122.5^{\circ} \mathrm{E}$ ) to Chichi-jima was calculated to be about 4-5 d based on the backward trajectories starting at 500, 1000, and $2000 \mathrm{~m}$ amsl.

The concentrations of levoglucosan over Chichi-jima were in general significantly lower than those observed at European low-level sites ( $\mathrm{PM}_{2.5}$, biannual averages: $309-517 \mathrm{ng} \mathrm{m}^{-3}$; Puxbaum et al., 2006) and in Chinese cities such as Beijing ( $\mathrm{PM}_{10}$, monthly averages: 120-1010 $\mathrm{ng} \mathrm{m}^{-3}$; Zhang et al., 2008). Furthermore, the concentrations of levoglucosan over Chichi-jima in the high-levoglucosan season (mean: $2.2 \mathrm{ng} \mathrm{m}^{-3}$ in winter) were even lower than those observed at European sites where the influence of biomass burning is expected to be low, e.g., at mountain sites $\left(\mathrm{PM}_{2.5}\right.$, biannual average: $\left.7.8-24.4 \mathrm{ng} \mathrm{m}^{-3}\right)$ and at a remote ocean sites $\left(\mathrm{PM}_{2.5}\right.$, biannual average: $5.2 \mathrm{ng} \mathrm{m}^{-3}$ in the Azores, in the Atlantic; Puxbaum et al., 2006). The seasonal average over Chichi-jima in the winter was comparable to those at a remote Indian Ocean site Hamnimaadhoo (fine particulate matter, range: 1.97-8.62 $\mathrm{ng} \mathrm{m}^{-3}$; Stone et al., 2007) and in the polar region (Zeppelin (PM2.5): $\leq 3 \mathrm{ng} \mathrm{m}^{-3}$ (Stohl et al., 2007); Alert (TSP): $\leq 1 \mathrm{ng} \mathrm{m}^{-3}$ (Fu et al., 2009)). The concentrations of levoglucosan in Chichi-jima were among the lowest recorded over surface sites.

The concentrations of OC and EC over Chichi-jima are presented in Fig. 2b and summarized in Table 1. The concentrations of OC and EC ranged 160-1700 $\mathrm{ng} \mathrm{m}^{-3}$ and $\leq 10-550 \mathrm{ng} \mathrm{m}^{-3}$, respectively. The range of EC concentration was comparable to the average concentrations of BC over Chichi-jima from 2000 to 2002 (157-474 $\mathrm{ng} \mathrm{m}^{-3}$ depending on the source region (after data screening); Koga et al., 2007). The mean concentration of OC in the winter was 3.2 times higher than that of EC (Table 1). The ratio is similar to those of submicron particles in the outflow of East Asian air masses (2.5-3.7) reported by shipboard measurements 
(Lim et al., 2003). Although EC showed seasonal variations similar to levoglucosan, a clear seasonal variation of OC was not observed. This implies substantial input of OC from marine (e.g., Fang et al., 2002) and local-terrestrial (e.g., primary biological) sources as well as secondary photochemical formation in the summer.

\subsection{Comparison with biomass-burning source emissions}

We compared the ratios of levoglucosan to OC and EC over Chichi-jima to those of biomass-burning source emissions to assess the influence of biomass burning on the concentration of levoglucosan over Chichi-jima. Fig. 4 plots the ratios of levoglucosan/EC versus levoglucosan/OC for aerosols over Chichi-jima and those from various emission sources. While the ratios for the source emissions range across an order of magnitude, both ratios of levoglucosan/OC and levoglucosan/EC in Chihi-jima aerosols were in most cases orders of magnitude lower than the ratios for biomass-burning source emissions.

If we assume that biomass-burning aerosols that reached Chichi-jima initially had the profile of Chinese cereal straw burning (Zhang et al., 2007), the observed ratios are reasonably explained by mixing biomass-burning aerosols with non-biomass-burning aerosols (dashed red lines in Fig. 4) and/or the possible degradation of levoglucosan during transport (solid blue line in Fig. 4). As shown in ten-day backward trajectories in Figs. 5a and b, the levoglucosan/OC ratios were generally high when air masses arrived directly from Asia and low when air masses stayed over the Pacific for more than $10 \mathrm{~d}$. Although the tendency is weaker for levoglucosan/EC ratios, significantly lower values for levoglucosan/EC ratios were mostly observed for the air mass trajectories that stagnated over the Pacific. Because the local emissions/formation of OC and EC, if they exist, may affect the ratios differently in time, the similar patterns in Figs. 5a and 5b were probably controlled by long-range transported aerosols, rather than by locally-formed/released aerosols. These variations result in the apparent contributions of biomass burning to $\mathrm{OC}$ ( $\mathrm{or}$ EC) in Chichi-jima aerosols being $0.035-24 \%$ (or $\leq 0.044-18 \%$ ), as estimated from the ratios of levoglucosan/OC (or levoglucosan/EC) in Figure 4, based on the assumptions that levoglucosan is chemically stable during transport and that the ratios over Chichi-jima were simply the result of mixing Chinese straw burning aerosols with non-biomass burning aerosols. The estimated contributions were, however, probably biased by the decomposition of levoglucosan as well as by the variations of actual source profiles. The possibility of degradation is further discussed below.

\subsection{Comparison between measured and modeled concentrations of levoglucosan}


To assess the stability of levoglucosan during transport, the measured concentration was compared to that estimated using SPRINTARS. Fig. 6 presents $\mathrm{OC}_{\mathrm{BB} \text {,model }}, \mathrm{OC}_{\text {model, }}, \mathrm{EC}_{\mathrm{BB} \text {,model }}$, and $\mathrm{EC}_{\text {model }}$, as well as the concentration of levoglucosan estimated using the model output. The measured concentrations of OC, EC, and levoglucosan are also presented. The model output suggests that the contribution of biomass burning to OC and EC sporadically increases, and the contribution was generally more significant for OC than EC (Figs. 6a and b). The underestimation of the sum of biomass-burning and non-biomass-burning OC may be partly due to the fact that inputs of marine and local terrestrial sources are not considered in the model. Uncertainties in the emission inventories of primary OC and secondary organic aerosol formation could also be responsible for part of the underestimation. For EC, the model output agrees reasonably well with the measured concentration.

As seen in Fig. 6c, the concentrations of levoglucosan estimated from $\mathrm{OC}_{\mathrm{BB} \text {,model }}$ and $\mathrm{EC}_{\mathrm{BB} \text {,model }}$ in the spring, summer and autumn are significantly higher than the measured concentrations, whereas those estimated and measured for the winter are comparable. The ratios of modeled to measured concentrations of levoglucosan are summarized in Table 2. The overestimation of the levoglucosan concentrations in the spring summer, and autumn implies significant chemical decomposition during long-range transport, although uncertainties in the model estimate may also be responsible for the discrepancy. Conversely, the ratios of measured to predicted levoglucosan concentrations in the winter show a better agreement. The similar concentration level in the winter suggests that the variation of the concentrations of levoglucosan over Chichi-jima represents the contribution of biomass-burning aerosols as a result of the shorter residence time. We note, however, that a bias caused by the decomposition of levoglucosan on QFFs during the sampling time in addition to that during atmospheric transport is not fully ruled out, although no significant change over $8 \mathrm{~h}$ was reported for levoglucosan spiked on filters (Locker, 1988). We also note that levoglucosan concentrations cannot be estimated for some data points with negative $\mathrm{OC}_{\mathrm{BB} \text {,model }}$ or $\mathrm{EC}_{\mathrm{BB} \text {,model. }}$ This results in the relatively small number of the winter concentration of levoglucosan estimated from $\mathrm{EC}_{\mathrm{BB} \text {,model }}$, which is however compensated with that estimated from $\mathrm{OC}_{\mathrm{BB} \text {,model }}$ (Fig. 6c).

\subsection{Comparison to the ratios of levoglucosan to $\mathrm{OC}$ and EC over the coastal region of East Asia}

The comparison of levoglucosan/OC and levoglucosan/EC ratios over Chichi-jima to those over coastal China provides further information on the stability of levoglucosan. Fig. 7 presents the seasonal variations of levoglucosan/OC and levoglucosan/EC over Chichi-jima, together with the ratios estimated from reported OC, EC and levoglucosan in $\mathrm{PM}_{2.5}$ over Changdao Island $\left(38^{\circ} \mathrm{N}\right.$ and $121^{\circ} \mathrm{E}$; Feng et al., 2007), which is located 
near the source region and close to the trajectories of air masses with high concentrations of levoglucosan (Fig.

3). The seasonal values for Chichi-jima aerosols are summarized in Table 2.

While the concentrations of levoglucosan over Changdao (the seasonal mean in $\mathrm{PM}_{2.5}: 4.23-147.97 \mathrm{ng}$ $\mathrm{m}^{-3}$ ) was significantly higher than that over Chichi-jima, the levoglucosan/OC and levoglucosan/EC ratios at the two sites show some similarities. Since inputs of EC and levoglucosan are not expected over the Pacific, the difference of levoglucosan/EC over Chichi-jima and Changdao in the winter roughly provides an upper limit for the degradation of levoglucosan during transport by westerly/northwesterly winds; the small difference is qualitatively consistent with the results in Section 3.4. Note that the actual difference could be smaller if the EC over Changdao, which was quantified by the NIOSH protocol, is converted to one based on the IMPROVE protocol. Although levoglucosan/OC is less suited for the comparison because (1) organics may evaporate or condense during transport, (2) some OC may exist in a coarse mode, and (3) local biogenic OC sources may exist, the fact that the ratios of levoglucosan/OC at the two locations were closer in the winter than in the summer further suggests a limited degree of decomposition of levoglucosan during transport by westerly/northwesterly winds. The lower levoglucosan/OC and levoglucosan/EC ratios at the two locations in the summer agrees with the assignment of summer aerosols over Changdao as maritime (Feng et al., 2007), in contrast to the absence of a clear decrease in levoglucosan/OC over an inland site, Beijing (Zhang et al., 2008). A low concentration of levoglucosan relative to OC and EC may be a general characteristic of aerosols over the western Pacific in the summer.

\subsection{Implications for the chemical stability of levoglucosan}

The disagreement between measured and modeled concentrations of levoglucosan, particularly in the summer (Fig. 5), suggests limited chemical stability in the atmosphere, although these results are possibly affected by uncertainties in the model outputs and further processing of levoglucosan on QFFs during the sampling. Based on a laboratory kinetics study and a model simulation, Hoffmann et al. (2010) estimated that levoglucosan decreases to half of its initial value in the atmosphere in $12.7-83.2 \mathrm{~h}$ at $90 \%$ relative humidity, mainly by a reaction with $\mathrm{OH}$. A long residence time over the Pacific in the summer, in many cases more than $10 \mathrm{~d}$, could be sufficient for the loss of levoglucosan by OH. Conversely, the limited degradation in the winter may be roughly explained by a shorter transport time ( $4-5 \mathrm{~d})$ and the upper end of the oxidation timescale in Hoffmann et al. (2010), with a consideration of uncertainties in the present study. The concentration of another key oxidant, $\mathrm{O}_{3}$, is high over Chichi-jima in the winter (monthly average: $>40$ ppbv, Kato et al., 2001). 
However, at least the direct ozonolysis of levoglucosan, a compound without a double bond, must be insignificant, although $\mathrm{O}_{3}$ may interact with saturated organics in complex pathways (Bailey, 1978).

Fraser and Lakshmanan (2000) reported the stability of levoglucosan against acid-catalyzed hydrolysis for $10 \mathrm{~d}$. Similarly, the timescale of the hydrolysis of levoglucosan in an acidified pyrolysis oil extract (sulfuric acid: $500 \mathrm{mM}$ ) at $298 \mathrm{~K}$, which can be calculated using the Arrhenius model, is very long ( 100 d; Helle et al., 2007). In contrast, Holmes and Petrucchi (2006) reported acid-catalyzed reactions in $0.5-7 \mathrm{~d}$, although the magnitude of the decrease in levoglucosan is not presented. Although the estimate of the stability of levoglucosan in the present study depends on several assumptions explained earlier, the results imply that the timescale for the acid-catalyzed reactions is not significantly shorter than 4-5 d. Conversely, the contribution for aerosols transported over $10 \mathrm{~d}$ is not clear. We also note a large abundance of D-glucose, an acid-catalyzed hydrolysis product of levoglucosan (Fig. S2 in the supplemental material). If D-glucose is also counted as levoglucosan with a correction for molecular weights, the seasonal averages of this hypothetical concentration reached 0.84-5.2 times the concentration of levoglucosan predicted by $\mathrm{OC}_{\mathrm{BB} \text {,model }}$. Although D-glucose may also be from primary biological particulate emissions, the large abundance leaves room for the possibility of acid-catalyzed hydrolysis.

\section{Summary}

We obtained three-year seasonal variations of levoglucosan, OC and EC over Chichi-jima in the western North Pacific. Levoglucosan showed a seasonal variation with a maximum in autumn and winter. Backward trajectory analysis showed that concentrations of levoglucosan were strongly influenced by Asian outflow, which was in general higher when the air masses were directly transported from Asia with westerly/northwesterly winds in about 4-5 d. A comparison of measured levoglucosan concentrations with those estimated from global aerosol model outputs and of levoglucosan/OC and levoglucosan/EC ratios over Chichi-jima to those at an Asian coastal site suggest that levoglucosan is relatively stable during transport from the Asian continent by westerly/northwesterly winds. From spring to autumn, the model estimate disagrees with the measurements, which may be due to the degradation of levoglucosan during transport for $10 \mathrm{~d}$ or more. The oxidative degradation by $\mathrm{OH}$ reasonably explains the discrepancy between the observations and the model outputs, whereas the contributions of the acid-catalyzed reactions need further studies, including the possible formation of D-glucose. This study suggests that the concentrations of levoglucosan at remote locations should be treated with caution in source apportionment studies. 


\section{Acknowledgments}

N. Umemoto and A. Kurokawa are gratefully acknowledged for their help with chemical analysis. We thank JAXA/Tokyo Bika Co. Ltd. for the use of the sampling site and help with sample collection, and Tokyo Dylec Corp. for help with the OC/EC determination of the filter samples. We also thank the people who contributed to the development of SPRINTARS. The SPRINTARS simulation in this study was performed on the NIES supercomputer system (NEC SX-8R). We gratefully acknowledge the NOAA Air Resources Laboratory (ARL) for providing the HYSPLIT transport model. This work was supported in part by MEXT, Japan through Grants-in-Aid 14204055 and 17340166 and the Program for Improvement of Research Environment for Young Researchers from Special Coordination Funds for Promoting Science and Technology.

\section{References}

Bailey, P.S., 1978. Ozonation in Organic Chemistry, in: Trahanovsky W. (Ed), Organic Chemistry, Academic Press, New York, Volume I, Olefinic Compounds.

Chow, J.C., Watson, J.G., Crow, D., Lowenthal, D.H., Merrifield, T., 2001. Comparison of IMPROVE and NIOSH Carbon Measurements. Aerosol Science and Technology 34, 23-34.

Draxler, R.R., Hess, G.D., 1997. Description of the HYSPLIT_4 modeling system. NOAA Technical Memorandum ERL ARL-224.

Draxler, R.R., Hess, G.D., 1998. An overview of the HYSPLIT_4 modeling system for trajectories, dispersion and deposition. Australian Meteorological Magazine 47, 295-308.

Elias, V.O., Simoneit, B.R.T., Cordeiro, R.C., Turcq, B., 2001. Evaluating levoglucosan as an indicator of biomass burning in Carajás, Amazônia: A comparison to the charcoal record. Geochimica et Cosmochimica Acta 65, 267-272.

Engling, G., Lee, J.J., Tsai, Y.-W., Lung, S.-C.C., Chou, C.C.-K., Chan C.-Y., 2009. Size-resolved anhydrosugar composition in smoke aerosol from controlled field burning of rice straw. Aerosol Science and Technology 43, 662-672.

Fang, J., Kawamura, K., Ishimura, Y., Matsumoto, K., 2002. Carbon isotopic composition of fatty acids in the marine aerosols from the western North Pacific: Implication for the source and atmospheric transport. Environmental Science \& Technology 36, 2598-2604.

Feng, J., Guo, Z., Chan, C.K., and Fang, M., 2007. Properties of organic matter in PM2.5 at Changdao Island, 
China - A rural site in the transport path of the Asian continental outflow. Atmospheric Environment 41, $1924-1935$.

Fine, P.M., Cass, G.R., Simoneit, B.R.T., 2001. Chemical characterization of fine particle emissions from fireplace combustion of wood grown in the Northeastern United States. Environmental Science \& Technology 35, 2665-2675.

Fine, P.M., Cass, G.R., Simoneit B.R.T., 2002. Chemical characterization of fine particulate emissions from the fireplace combustion of woods grown in the Southern United States. Environmental Science \& Technology 36, 1442-1451.

Fine, P.M., Cass, G.R., Simoneit, B.R.T., 2004a. Chemical characterization of fine particle emissions from the fireplace combustion of wood types grown in the midwestern and western United States. Environmental Engineering Science 21, 387-409.

Fine, P. M., Cass, G. R., Simoneit, B. R. T., 2004b. Chemical characterization of fine particle emissions from the wood stove combustion of prevalent United States tree species. Environmental Engineering Science $21,705-721$.

Fraser, M.P., Lakshmanan, K., 2000. Using levoglucosan as a molecular marker for the long-range transport of biomass combustion aerosols. Environmental Science \& Technology 34, 4560-4564.

Frey, A.K., Tissari, J., Saarnio, K.M., Timonen, H.J., Tolonen-Kivimäki, O., Aurela, M.A., Saarikoski, S.K., Makkonen, U., Hytönen, K., Jokiniemi, J., Salonen, R.O., Hillamo, R.E.J., 2009. Chemical composition and mass size distribution of fine particulate matter emitted by a small masonry heater. Boreal Environment Research 14, 255-271.

Fu, P.-Q., Kawamura, K., Barrie, L.A., 2009. Photochemical and other sources of organic compounds in the Canadian arctic aerosol pollution during winter-spring. Environmental Science \& Technology 43, $286-292$.

Gambaro, A., Zangrando, R., Gabrielli, P., Barbante, C., Cescon, P., 2008. Direct determination of levoglucosan at the picogram per milliliter level in Antarctic ice by high-performance liquid chromatography/electrospray ionization triple quadrupole mass spectrometry. Analytical Chemistry, 80, $1649-1655$.

Graham, B., Mayol-Bracero, O.L., Guyon, P., Roberts, G.C., Decesari, S., Facchini, M.C., Artaxo, P., Maenhaut, W., Köll, P., Andreae, M.O., 2002. Water-soluble organic compounds in biomass burning aerosols over Amazonia 1. Characterization by NMR and GC-MS. Journal of Geophysical Research 107 
(D20), 8047 doi:10.1029/2001JD000336.

Hays, M.D., Geron, C.D., Linna, K.J., Smith, N.D., 2002. Speciation of gas-phase and fine particle emissions from burning of foliar fuels. Environmental Science \& Technology 36, 2281-2295.

Hays, M.D., Fine, P.M., Geron, C.D., Kleeman, M.J., Gullett, B.K., 2005. Open burning of agricultural biomass: Physical and chemical properties of particle-phase emissions, Atmospheric Environment 39, $6747-6764$.

Helle, S., Bennett, N.M., Lau, K., Matsui, J.H., Duff, S.J.B., 2007. A kinetic model for production of glucose by hydrolysis of levoglucosan and cellobiosan from pyrolysis oil. Carbohydrate Research 342, $2365-2370$.

Hoffmann, D., Tilgner, A., Iinuma, Y., Hermann, H., 2010, Atmospheric stability of levoglucosan: A detailed laboratory and modeling study. Environmental Science \& Technology 44, 694-699.

Holmes, B.J., Petrucci, G.A., 2006. Water-soluble oligomer formation from acid-catalyzed reactions of levoglucosan in proxies of atmospheric aqueous aerosols. Environmental Science \& Technology 40, 4983-4989.

Iinuma, Y., Brüggemann, E., Gnauk, T., Muller, K., Andreae, M.O., Helas, G., Parmar, R., Hermann, H., 2007. Source characterization of biomass burning particles: The combustion of selected European conifers, African hardwood, savanna grass, and German and Indonesian peat. Journal of Geophysical Research 112, D08209, doi:10.1029/2006JD007120.

Kato S., Pochanart, P., Kajii, Y., 2001. Measurements of ozone and nonmethane hydrocarbons at Chichi-jima island, a remote island in the western Pacific: long-range transport of polluted air from the Pacific rim region. Atmospheric Environment 35, 6021-6029.

Kawamura, K., Ishimura, Y., and Yamazaki, K., 2003. Four years' observation of terrestrial lipid class compounds in marine aerosols from the western North Pacific. Global Biogeochemical Cycles 17, NO. 1, 1003, doi:10.1029/2001GB001810.

Koga, S., Maeda, T., Kaneyasu, N., 2008. Source contributions to black carbon mass fractions in aerosol particles over the northwestern Pacific. Atmospheric Environment 42, 800-814.

Lee, S., Baumann, K., Schauer, J.J., Sheesley, R.J., Naeher, L.P., Meinardi, S., Brake, D.R., Edgerton, E.S., Russell, A.G., Clements, M., 2005. Gaseous and particulate emissions from prescribed burning in Georgia. Environmental Science \& Technology 39, 9049-9056.

Lim, H.-J., Turpin, B.J., Russell, L.M., Bates, T.S., 2003. Organic and elemental carbon measurements during 
ACE-Asia measurements suggest a longer atmospheric lifetime for elemental carbon. Environmental Science \& Technology 37, 3055-3061.

Locker, H.B., 1988. The use of levoglucosan to assess the environmental impact of residential wood-burning on air quality. Ph.D. thesis, Dartmouth College, Hanover, NH.

Mazzoleni, L.R., Zielinska, B., Moosmüller, H., 2007. Emissions of levoglucosan, methoxy phenols, and organic acids from prescribed burns, laboratory combustion of wildland fuels, and residential wood combustion. Environmental Science \& Technology 41, 2115-2122.

Mochida, M., Kawamura, K., Umemoto, N., Kobayashi, M., Matsunaga, S., Lim, H.-J., Turpin, B.J., Bates, T.S., Simoneit, B.R.T., 2003a. Spatial distributions of oxygenated organic compounds (dicarboxylic acids, fatty acids, and levoglucosan) in marine aerosols over the western Pacific and off the coast of East Asia: Continental outflow of organic aerosols during the ACE-Asia campaign. Journal of Geophysical Research 108 (D23), 8638, doi:10.1029/2002JD003249.

Mochida, M., Kawabata, A., Kawamura, K., Hatsushika., H., Yamazaki, K., 2003b. Seasonal variation and origins of dicarboxylic acids in the marine atmosphere over the western North Pacific. Journal of Geophysical Research 108(D6), 4193, doi:10.1029/2002JD002355.

Mochida, M., Umemoto, N., Kawamura, K., Lim, H.-J., Turpin, B.J., 2007. Bimodal size distributions of various organic acids and fatty acids in the marine atmosphere: Influence of anthropogenic aerosols, Asian dusts, and sea spray off the coast of East Asia, Journal of Geophysical Research 112, D15209, doi:10.1029/2006JD007773.

Oros, D.R., Simoneit, B.R.T., 2001a. Identification and emission factors of molecular tracers in organic aerosols from biomass burning Part 1. Temperate climate conifers. Applied Geochemistry 16, 1513-1544.

Oros, D.R., Simoneit, B.R.T., 2001b. Identification and emission factors of molecular tracers in organic aerosols from biomass burning Part 2. Deciduous trees. Applied Geochemistry 16, 1545-1565.

Oros, D.R., bin Abas, M.R., Omar, N.Y.M.J., Rahman, N.A., Simoneit, B.R.T., 2006. Identification and emission factors of molecular tracers in organic aerosols from biomass burning Part 3, Grasses. Applied Geochemistry 21, 919-940.

Puxbaum, H., Caseiro, A., Sánchez-Ochoa, A., Kasper-Giebl, A., Claeys, M., Gelencsér, A., Legrand, M., Preunkert, S., Pio, C., 2006. Levoglucosan levels at background sites in Europe for assessing the impact of biomass combustion on the European aerosol background. Journal of Geophysical Research 112 , D23S05, doi:10.1029/2006JD008114. 
Schauer, J.J., Kleeman, M.J., Cass, G.R., Simoneit, B.R.T., 2001. Measurement of emissions from air pollution sources. 3. $\mathrm{C}_{1}-\mathrm{C}_{29}$ Organic compounds from fireplace combustion of wood. Environmental Science \& Technology 35, 1716-1728.

Schmidl, C., Marr, I.L., Caseiro, A., Kotianová, P., Berner, A., Bauer, H., Kasper-Giebl, A., Puxbaum, H., 2008a. Chemical characterization of fine particle emissions from wood stove combustion of common woods growing in mid-European Alpine regions. Atmospheric Environment 42, 126-141.

Schmidl, C., Bauer, H., Dattler, A., Hitzenberger, R., Weissenboeck, G., Marr, I.L., Puxbaum, H., 2008b. Chemical characterization of particle emissions from burning leaves. Atmospheric Environment 42, 9070-9079.

Sheesley, R.J., Schauer, J.J., Chowdhury, Z., Cass, G.R., Simoneit, B.R.T., 2003. Characterization of organic aerosols emitted from the combustion of biomass indigenous to South Asia. Journal of Geophysical Research 108(D9), 4285, doi:10.1029/2002JD002981.

Simoneit, B.R.T., 2002. Biomass burning - a review of organic tracers for smoke from incomplete combustion. Applied Geochemistry 17, 129-162.

Stohl, A., Berg, T., Burkhart, J.F., Fjæraa, A.M., Forster, C., Herber, A., Hov, Ø., Lunder, C., McMillan, W.W., Oltmans, S., Shiobara, M., Simpson, D., Solberg, S., Stebel, K., Ström, J., Tørseth, K., Treffeisen, R., Virkkunen, K., Yttri, K.E., 2007. Arctic smoke - record high air pollution levels in the European Arctic due to agricultural fires in Eastern Europe in spring 2000. Atmospheric Chemistry and Physics 7, $511-534$.

Stone, E.A., Lough, G.C., Schauer, J.J., Praveen, P.S., Corrigan, C.E., Ramanathan, V., 2007. Understanding the origin of black carbon in the atmospheric brown cloud over the Indian Ocean. Journal of Geophysical Research 112, D22S23, doi:10.1029/2006JD008118.

Sullivan, A.P., Holden, A.S., Patterson, L.A., McMeeking, G.R., Kreidenweis, S.M., Malm, W.C., Hao, W.M., Wold, C.E., Collett Jr., J.L., 2008. A method for smoke marker measurements and its potential application for determining the contribution of biomass burning from wildfires and prescribed fires to ambient PM2.5 organic carbon, Journal of Geophysical Research 113, D22302, doi:10.1029/2008JD010216.

Takemura, T., Okamoto, H., Maruyama, Y., Numaguti, A., Higurashi, A., Nakajima, T., 2000. Global three-dimensional simulation of aerosol optical thickness distribution of various origins. Journal of Geophysical Research 105, 17853-17873.

Takemura, T., Egashira, M., Matsuzawa, K., Ichijo, H., O'ishi, R., Abe-Ouchi, A., 2009. A simulation of the 
global distribution and radiative forcing of soil dust aerosols at the Last Glacial Maximum. Atmospheric Chemistry and Physics 9, 3061-3073.

Wang, G., Kawamura, K., 2005. Molecular characteristics of urban organic aerosols from Nanjing: A case study of a mega-city in China. Environmental Science \& Technology 39, 7430-7438.

Wang, G., Kawamura, K., Xie, M., Hu, S., Cao, J., An, Z., Watson, J.G., Chow, J.C., 2009. Organic molecular compositions and size distributions of Chinese summer and autumn aerosols from Nanjing: Characteristic Haze Event caused by wheat straw burning. Environmental Science \& Technology 43, 6493-6499

Zhang, Y.-X., Shao, M., Zhang, Y.-H., Zeng, L.-M., He, L.-Y., Zhu, B., Wei, Y.-J., Zhu, X.-L., 2007. Source profiles of particulate organic matters emitted from cereal straw burnings. J. Environmental Sciences 19, 167-175 (www.jesc.ac.cn).

Zhang, T., Claeys, M., Cachier, H., Dong, S., Wang, W., Maenhaut, W., Liu, X., 2008. Identification and estimation of the biomass burning contribution to Beijing aerosol using levoglucosan as a molecular marker. Atmospheric Environment 42, 7013-7021.

\section{Figure Captions}

Fig. 1. The sampling site (star), Chichi-jima, and the geodesic distance from the site.

Fig. 2. Three-year temporal variations in the concentrations of (a) levoglucosan and (b) OC and EC. The four different seasons are shown by the shaded areas. The bars show possible biases (Section 2.1).

Fig. 3. Ten-day backward trajectories of air masses that arrived over Chichi-jima in (a) December-February, (b) March-May, (c) June-August, and (d) September-November, colored according to the concentrations of levoglucosan.

Fig. 4. Plots of levoglucosan/EC versus levoglucosan/OC for Chichi-jima aerosols (circles color-coded according to concentrations of levoglucosan) and aerosols emitted from various biomass-burning sources (values from the literature are shown with other markers). The solid blue line shows the direction of changes caused by the degradation of levoglucosan. Expected changes of the ratios by mixing aerosols from Chinese straw burning (solid red diamond; Zhang et al., 2007) with non-biomass burning aerosols containing only OC, and OC and EC at ratios of 100:1, 10:1, and 1:1 
are represented by dashed red lines. References of other biomass-burning sources are Shauer et al. (2001), Oros and Simoneit (2001a), Oros and Simoneit (2001b and correction as personal communication from Simoneit), Fine et al. (2001, 2002, 2004a, 2004b), Hays et al. (2002, 2005), Sheesley et al. (2003), Lee et al. (2005), Oros et al. (2006), Iinuma et al. (2007), Mazzoleni et al. (2007), Schmidl et al. (2008a, 2008b), Sullivan et al. (2008), Engling et al. (2009), and Frey et al. (2009). Multiple values of the reference data for a single type of biomass are averaged, and the bars are the ranges among species/experiments. If the means of OC, EC and levoglucosan are available, the mean of levoglucosan is divided by that of OC (or EC) to approximate the levoglucosan/OC (or EC) ratios. Blue crosses represent upper limits of levoglucosan/EC for samples with ECs below the blank level. Further explanation is given in the supplemental material.

Fig. 5. (a) Ten-day backward trajectories of air masses arrived over Chichi-jima, colored by the levoglucosan/OC ratios. (b) Same as Fig. 5a, but colored according to the levoglucosan/EC ratios.

Fig. 6. Temporal variations of (a) $\mathrm{OC}_{\text {model }}$ (lightly shaded), $\mathrm{OC}_{\mathrm{BBmodel}}$ (darkly shaded), and measured $\mathrm{OC}$

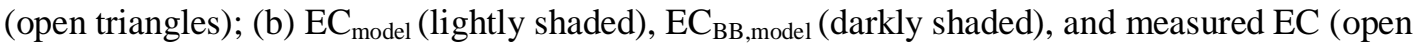
squares); and (c) levoglucosan estimated from $\mathrm{OC}_{\mathrm{BB} \text {,model }}$ (solid green lines) with hypothetical errors in levoglucosan/OC of sources $(-50 \%$ to $+100 \%$ : shaded with darker green, $-80 \%$ to $+400 \%$ : shaded with lighter green), levoglucosan estimated from $\mathrm{EC}_{\mathrm{BB} \text {,model }}$ (crosses), and measured levoglucosan (open circles).

Fig. 7. Temporal variations in (a) levoglucosan/OC and (b) levoglucosan/EC of individual samples (solid gray squares) and the monthly average (solid red circles with ranges shown by bars). The gray bars show possible biases (Section 2.1). The levoglucosan/OC (or EC) ratios in Changdao (horizontal solid bars) are estimated based on levoglucosan and $\mathrm{OC}$ (or EC) in $\mathrm{PM}_{2.5}$ samples reported by Feng et al. (2007). Blue crosses present upper limits of levoglucosan/EC for samples with EC below the blank level. 
Table 1. Seasonal Means and Ranges $\left(\mathrm{ng} \mathrm{m}^{-3}\right)$ of the Concentrations of Levoglucosan, OC, and EC over Chichi-jima ${ }^{\mathrm{a}}$

\begin{tabular}{ccccccccc}
\hline & $\begin{array}{c}\text { December-February } \\
(\text { winter, } n=37)\end{array}$ & \multicolumn{2}{c}{$\begin{array}{c}\text { March-May } \\
(\text { spring, } n=37)\end{array}$} & \multicolumn{2}{c}{$\begin{array}{c}\text { June-August } \\
(\text { summer, } n=36)\end{array}$} & \multicolumn{2}{c}{$\begin{array}{c}\text { September-November } \\
(\text { autumn, } n=38)\end{array}$} \\
& Mean & $($ Range $)$ & Mean & (Range) & Mean & (Range) & Mean & (Range) \\
\hline Levoglucosan & 2.2 & $(0.43-15)$ & 1.0 & $(0.038-9.0)$ & 0.32 & $(0.017-1.6)$ & 0.59 & $(0.014-2.5)$ \\
OC & 590 & $(150-1200)$ & 670 & $(180-1600)$ & 520 & $(150-1100)$ & 550 & $(260-1200)$ \\
EC & 180 & $(20-400)$ & $190^{\mathrm{b}}[160-170]^{\mathrm{c}}$ & $\left(\leq 10^{\mathrm{d}}-510\right)$ & $87^{\mathrm{b}}[41-54]^{\mathrm{c}}$ & $\left(\leq 20^{\mathrm{d}-160)}\right.$ & $140^{\mathrm{b}}[76-89]^{\mathrm{c}}$ & $\left(\leq 22^{\mathrm{d}}-320\right)$ \\
\hline
\end{tabular}

${ }^{\mathrm{a}}$ The samples are assigned to the seasons based on the middle time of the sampling period. ${ }^{\mathrm{b}}$ Samples within the blank level were omitted. ${ }^{\mathrm{c}}$ Possible ranges of mean values, including the samples below the blank level. ${ }^{\mathrm{d}}$ Calculated from the blank level. 
Table 2. Concentration Ratios for Studied Chemical Components

\begin{tabular}{|c|c|c|c|c|c|c|c|c|}
\hline & \multicolumn{2}{|c|}{$\begin{array}{c}\text { December-February } \\
\text { (winter) }\end{array}$} & \multicolumn{2}{|c|}{$\begin{array}{l}\text { March-May } \\
\text { (spring) }\end{array}$} & \multicolumn{2}{|c|}{$\begin{array}{l}\text { June-August } \\
\text { (summer) }\end{array}$} & \multicolumn{2}{|c|}{$\begin{array}{l}\text { September-November } \\
\text { (autumn) }\end{array}$} \\
\hline & Mean & (Range) & Mean & (Range) & Mean & (Range) & Mean & (Range) \\
\hline $\begin{array}{l}\text { (Measured levoglucosan) } \\
\text { /(modeled levoglucosan) }\end{array}$ & $2.2[0.96]^{\mathrm{a}}$ & - & $0.08[0.09]^{\mathrm{a}}$ & - & $0.04[0.03]^{\mathrm{a}}$ & - & $0.18[0.18]^{\mathrm{a}}$ & - \\
\hline Levoglucosan/OC & $3.8 \times 10^{-3}$ & $\begin{array}{l}\left(8.4 \times 10^{-4}\right. \\
\left.-2.0 \times 10^{-2}\right)\end{array}$ & $1.3 \times 10^{-3}$ & $\begin{array}{l}\left(4.6 \times 10^{-5}\right. \\
\left.-5.8 \times 10^{-3}\right)\end{array}$ & $6.2 \times 10^{-4}$ & $\begin{array}{l}\left(2.9 \times 10^{-5}\right. \\
\left.-4.4 \times 10^{-3}\right)\end{array}$ & $1.1 \times 10^{-3}$ & $\begin{array}{l}\left(2.9 \times 10^{-5}\right. \\
\left.-5.2 \times 10^{-3}\right)\end{array}$ \\
\hline Levoglucosan/EC & $1.6 \times 10^{-2}$ & $\begin{array}{l}\left(2.5 \times 10^{-3}\right. \\
\left.-9.0 \times 10^{-2}\right)\end{array}$ & $8.4 \times 10^{-3}$ & $\begin{array}{l}\left(3.8 \times 10^{-4}\right. \\
\left.-1.1 \times 10^{-1}\right)\end{array}$ & $6.5 \times 10^{-3}$ & $\begin{array}{l}\left(2.8 \times 10^{-4}\right. \\
\left.-4.8 \times 10^{-2}\right)\end{array}$ & $1.1 \times 10^{-2}$ & $\begin{array}{l}\left(1.2 \times 10^{-3}\right. \\
\left.-8.9 \times 10^{-2}\right)\end{array}$ \\
\hline
\end{tabular}

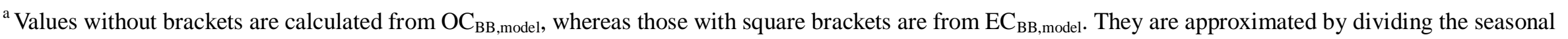
average of measured concentration (for samples whose $\mathrm{OC}_{\mathrm{BB} \text {,model }}\left(\right.$ or $\mathrm{EC}_{\mathrm{BB} \text {,model }}$ ) are available) by that estimated from $\mathrm{OC}_{\mathrm{BB} \text {,model }}$ (or $\mathrm{EC}_{\mathrm{BB}, \mathrm{model}}$ ). ${ }^{\mathrm{b}} \mathrm{Samples}$ below the blank level were omitted. 
Figure 1. Mochida et al.

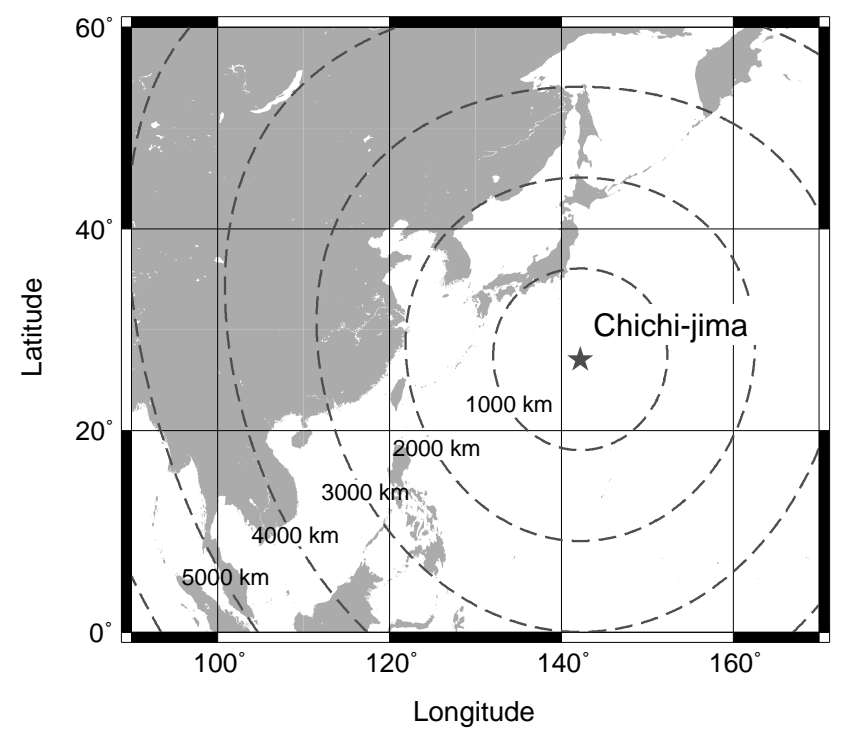


Figure 2. Mochida et al.

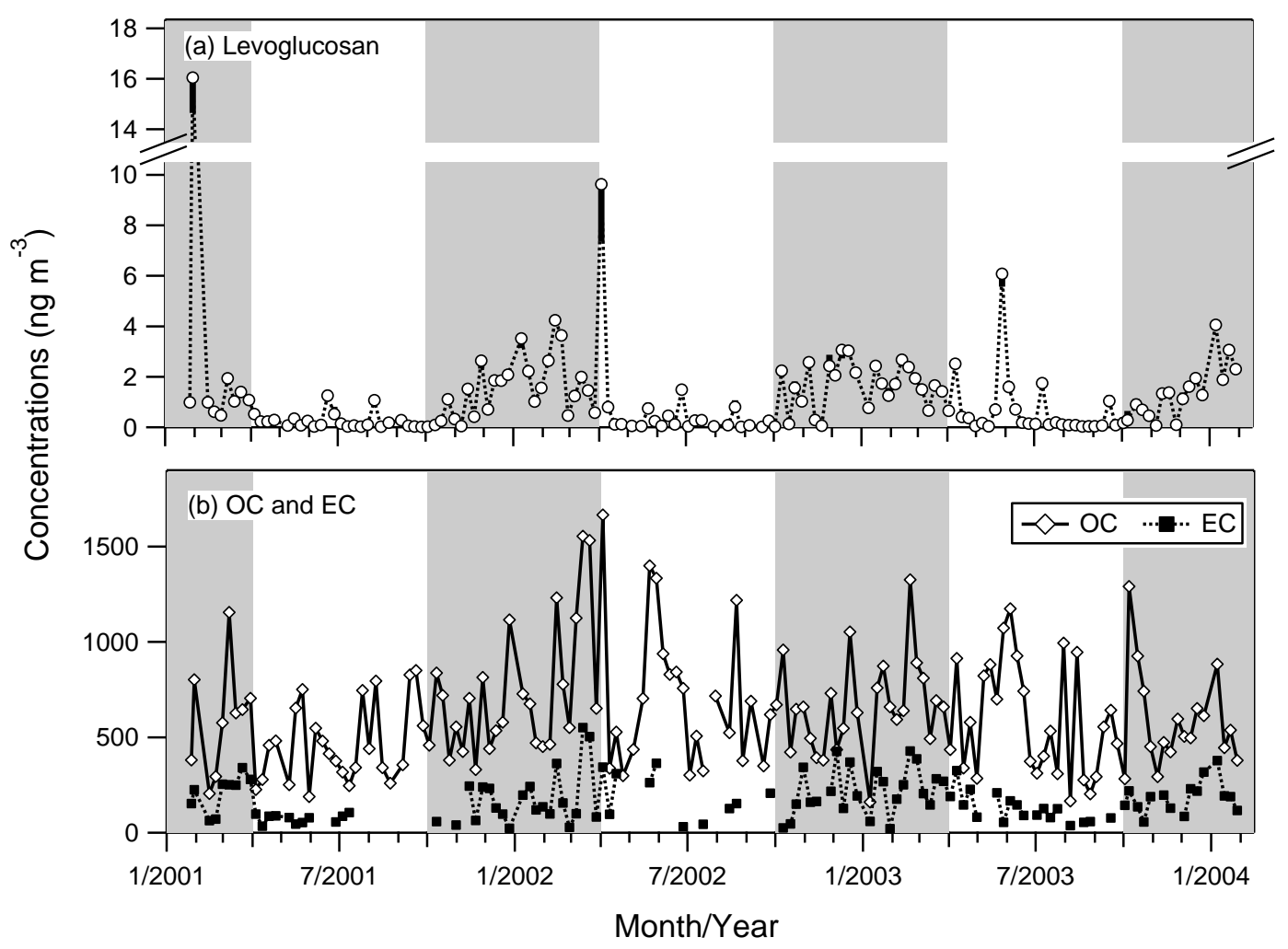


Figure 3. Mochida et al.

$\log _{10} C_{\text {levoglucosan }}\left(\mathrm{ng} \mathrm{m}^{-3}\right)$

$\begin{array}{llllll}-1.5 & -1.0 & -0.5 & 0.0 & 0.5 & 1.0\end{array}$

(a) January-March

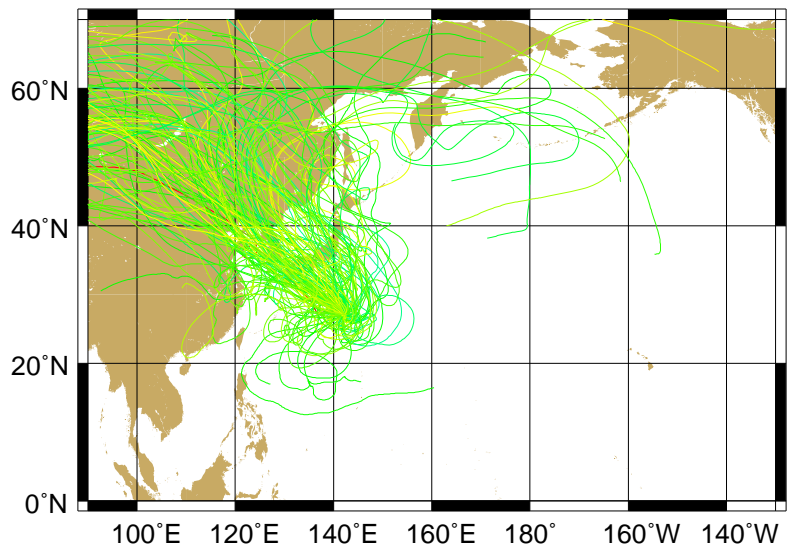

(b) April-June

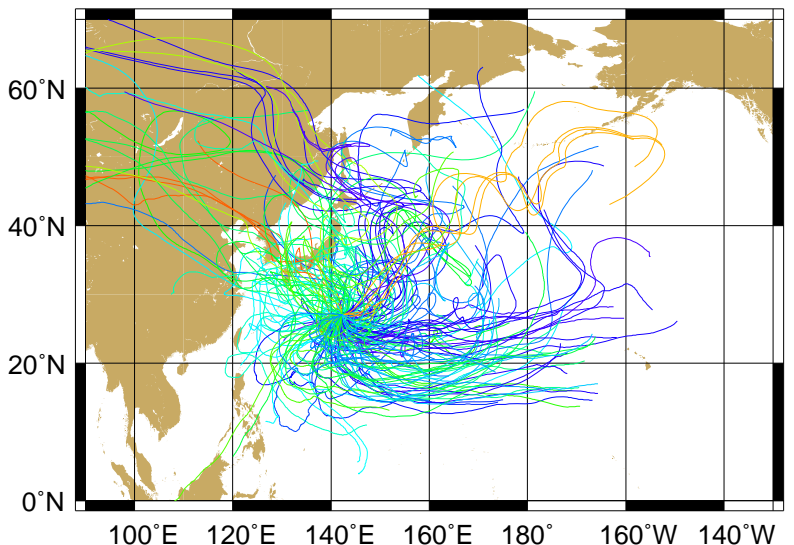

(c) July-September

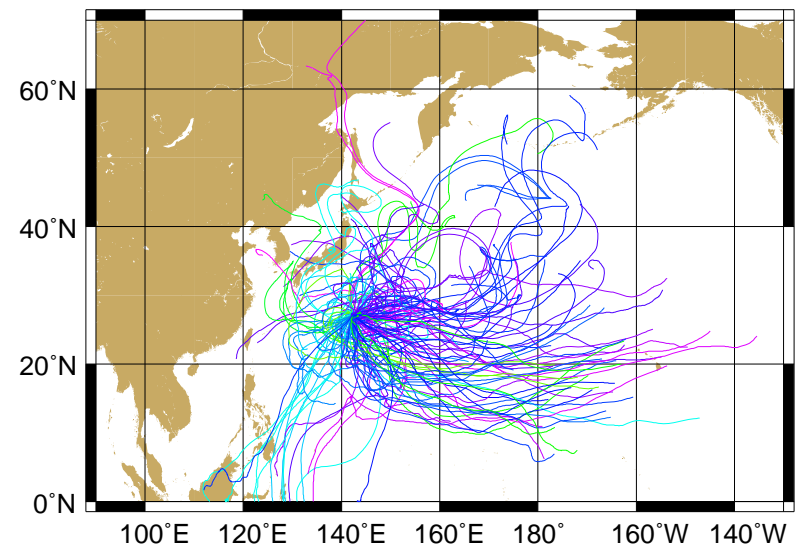

(d) October-December

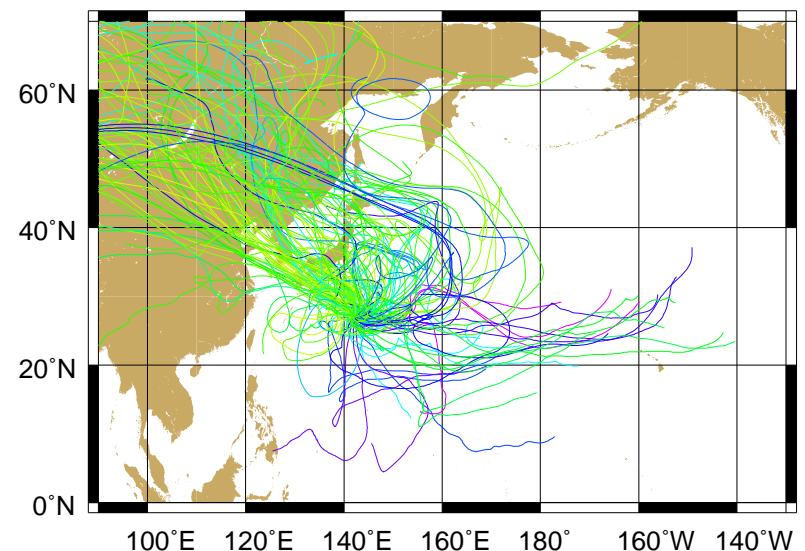

Longitude 
Figure 5. Mochida et al.

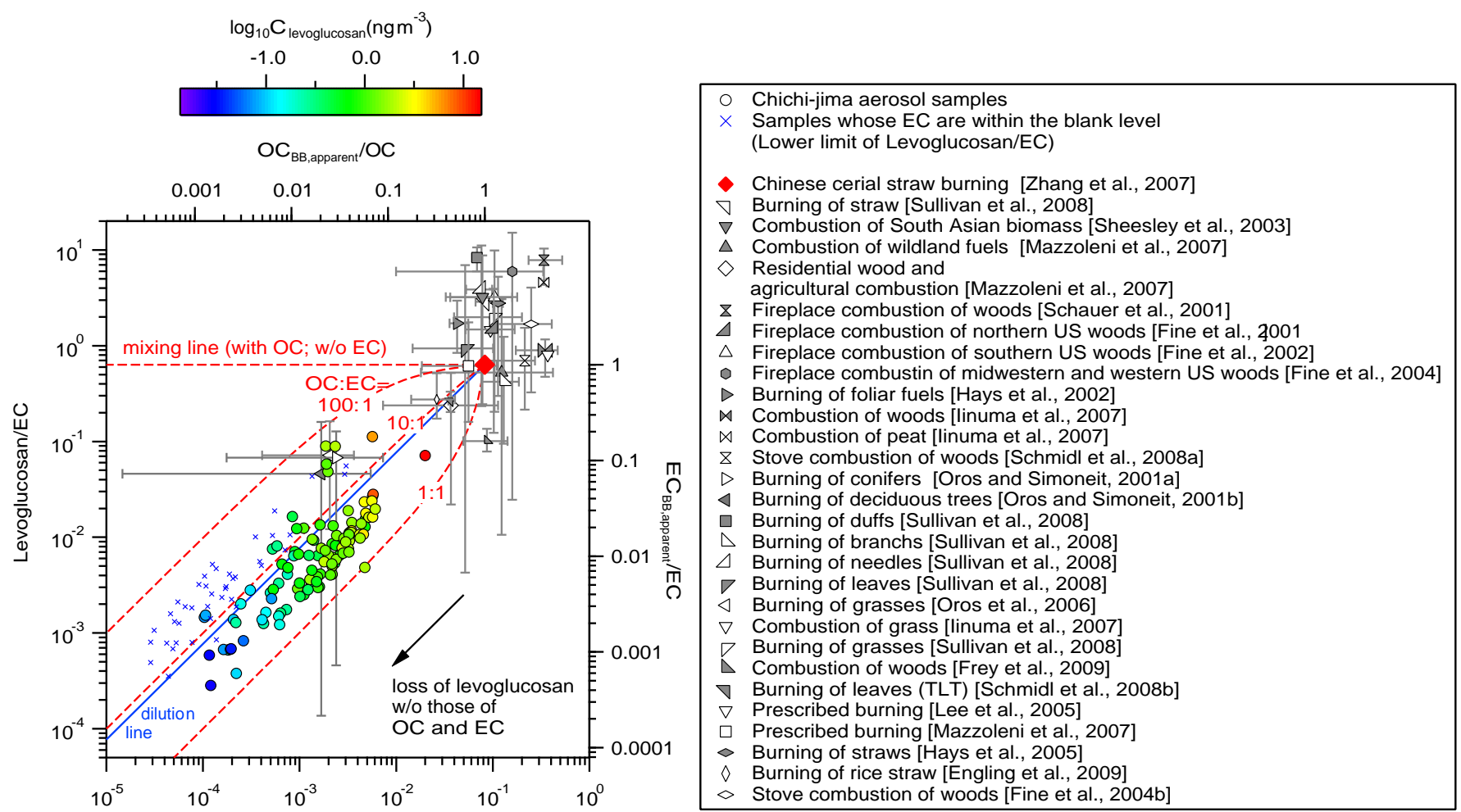

Levoglucosan/OC 
Figure 6. Mochida et al.

(a)

$\log _{10}\left(C_{\text {levoglucosan }} / \mathrm{C}_{\mathrm{OC}}\right)$

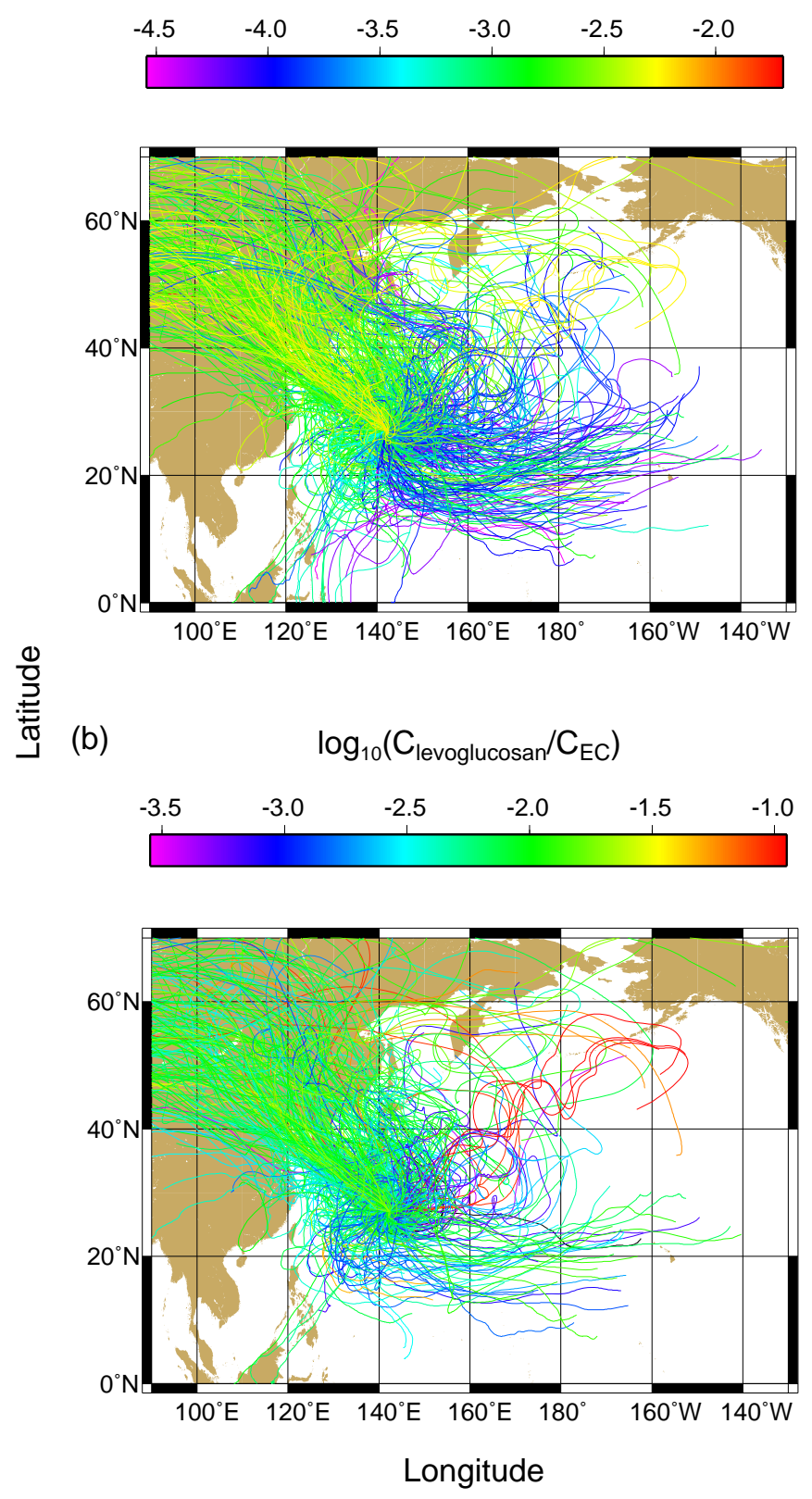


Figure 7. Mochida et al.
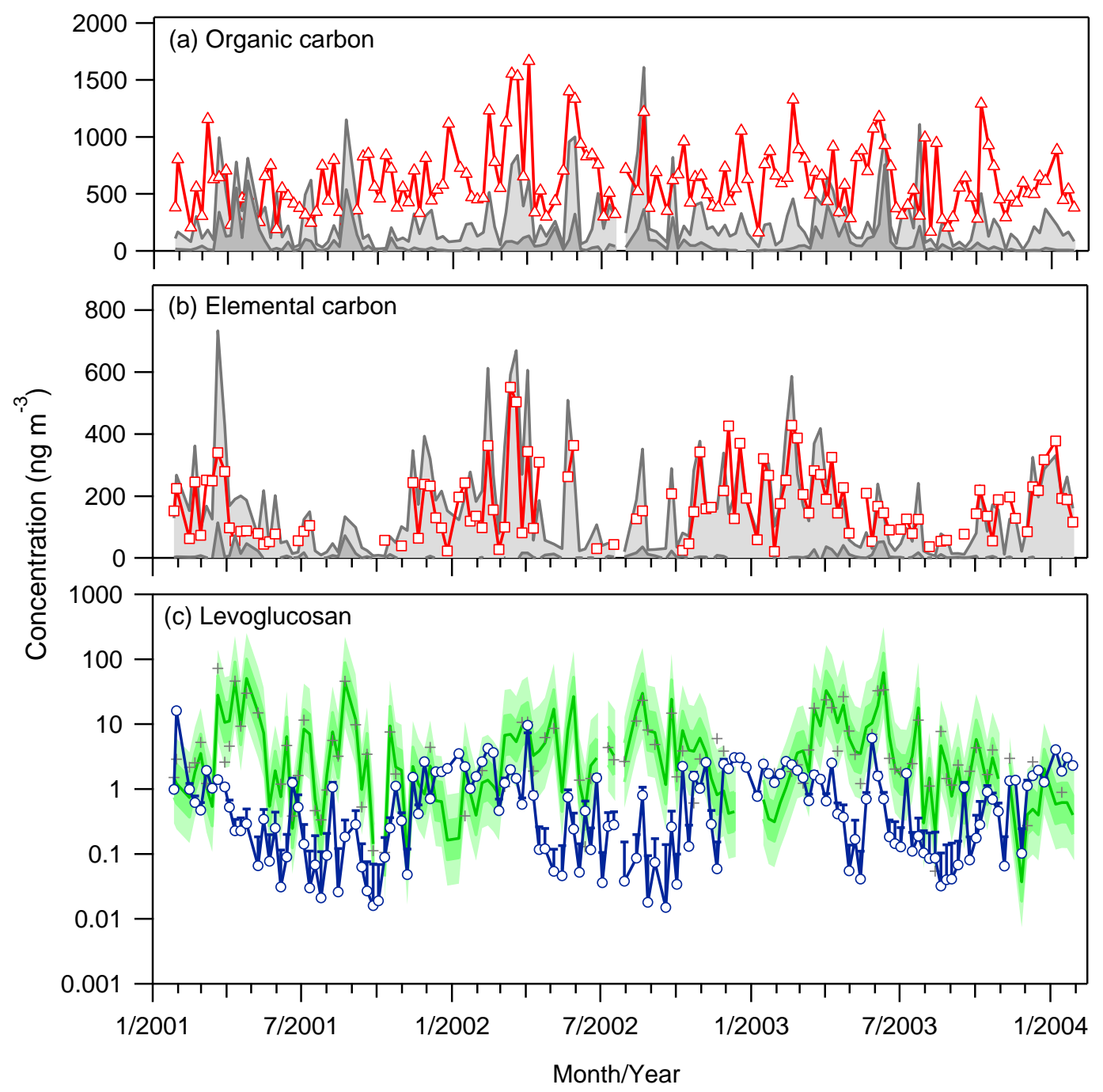
Figure 8. Mochida et al.

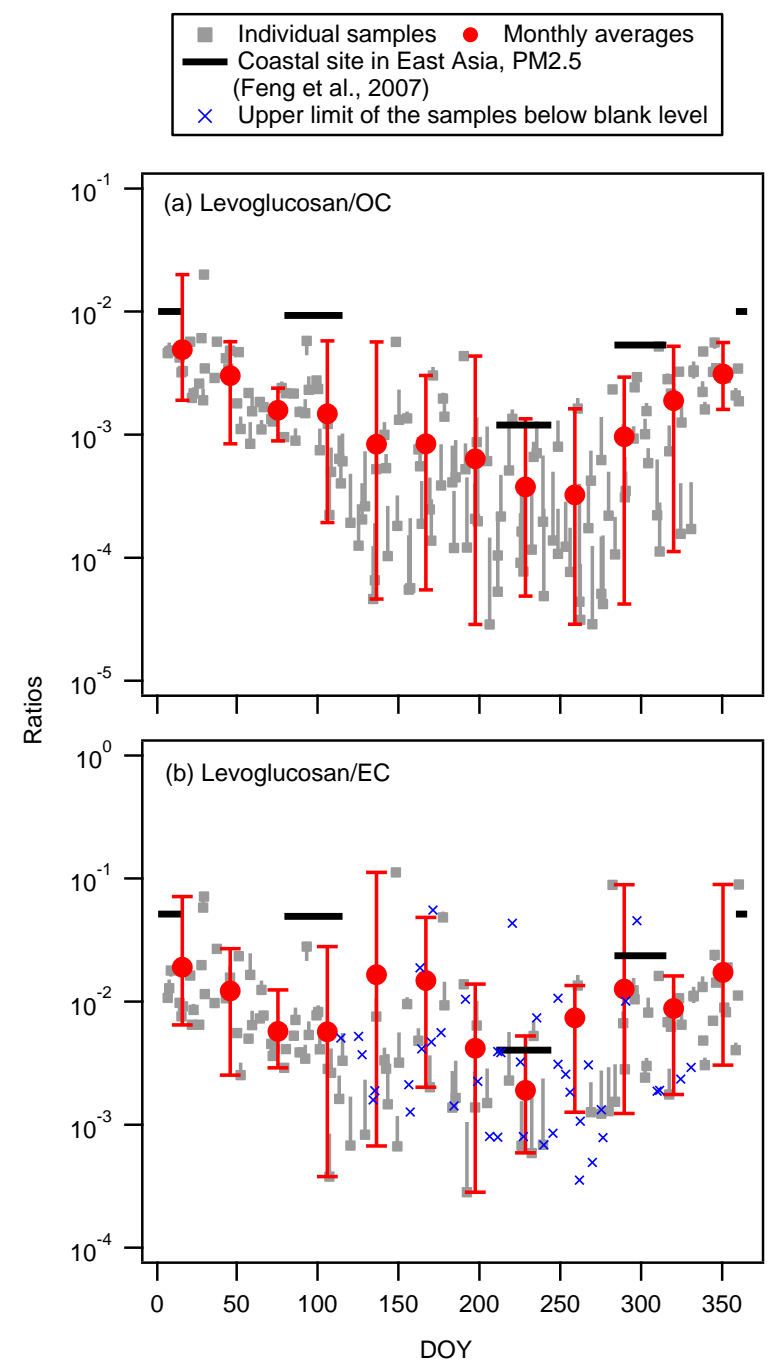

